\title{
Thermohaline Steps Induced By Melting of the Erebus Glacier Tongue
}

\author{
S. S. JACOBS
}

Lamont-Doherty Geological Observatory, Columbia University, Palisades, New York 10964

H. E. HUPPERT

Department of Applied Mathematics and Theoretical Physics

University of Cambridge, England

G. HOLDSWORTH

Environment Canada, Ottawa, Ontario

D. J. DREWRY

Scott Polar Research Institute, University of Cambridge, England

\begin{abstract}
A vertically stable, step-like thermohaline structure is observed throughout a continuous, $400 \mathrm{~m}$ conductivity-temperature-depth (CTD) profile taken near the Erebus Glacier Tongue, McMurdo Sound, Antarctica. The pattern is best developed between the sea surface and $250 \mathrm{~m}$ depth, the interval corresponding to that of the irregular underwater profile of the Glacier Tongue. The steps average $17 \mathrm{~m}$ in thickness and typically display discontinuities of $0.1^{\circ} \mathrm{C}$ in temperature, $0.04 \%$ in salinity and $3.5 \times 10^{-4}$ $\mathrm{g} \mathrm{cm}^{-3}$ in density. The observations are compared with theory and laboratory experiments of cell development and lateral flow near ice melting into vertically stratified salt water. At this location, subsurface seawater is inferred to remain above the in situ freezing point year-round, and contains sufficient heat to account for much of the Glacier Tongue thinning by basal melting. An adequate volume of meltwater would result to produce the measured salinity steps. We discuss related observations and some implications of this process for ocean circulation and biological productivity in the Antarctic.
\end{abstract}

\section{OCEANOGRAPHIC OBSERVATIONS}

In mid-February 1979 the U.S. Coast Guard icebreaker Glacier occupied several stations in the southern part of McMurdo Sound (Figure 1), including three near the end of the Erebus Glacier Tongue (EGT, Figure 2a). At that time, only the tip of the EGT protruded from the sea ice (Figure $2 b$ ). Stations 217-219 were located 250-500 m apart with 218 at the glacier terminus. At each position the ship's screw propellers were slowly rotated while its bow was held against the pack ice.

Temperature, conductivity, and pressure were measured between the sea surface and bottom with a Neil Brown conductivity/temperature/depth (CTD) instrument. The CTD lowering rate of approximately $40 \mathrm{~m} \mathrm{~min}^{-1}$ corresponded to one temperature and salinity value for each $2 \mathrm{~cm}$ of depth. The records were transferred from audio to digital tape and salinity computed from conductivity. Temperature and salinity bias corrections were applied from reversing thermometer and water sample data taken with a General Oceanics Rosette during ascent of the CTD.

Several of the stations revealed steps in temperature, salinity, and density that are more than an order of magnitude larger than resolution of the CTD instrument. The best-defined and most regular steps occurred on station 217 (Figure 3 ), and average $17 \mathrm{~m}$ in thickness. Within a temperature range of -1.2 to $-1.9^{\circ} \mathrm{C}$ and a salinity range of 34.2 to $34.8 \%$, the major steps display discontinuities of about $0.1^{\circ} \mathrm{C}$ in temperature, $0.04 \%$ in salinity, and $3.5 \times 10^{-4} \mathrm{~g} \mathrm{~cm}^{-3}$ in density. At these low temperatures, a salinity change of $0.04 \%$ has 10

Copyright (C) 1981 by the American Geophysical Union. times the impact on density $\left(\sigma_{\tau}\right)$ of a $0.1^{\circ} \mathrm{C}$ temperature change. Temperature is nearly isothermal below $250 \mathrm{~m}$, and more than $0.2^{\circ} \mathrm{C}$ above the in situ freezing point [Fujino et al., 1974] at all depths. Several of the station 217 steps can be identified on nearby station 218 , but the relative importance of spatial versus temporal changes could not be determined, as these stations were taken on an opportunity basis. The CTD records are relatively noisy, possibly due to system response time and slow sensor descent rate. The differing descent and ascent profiles, and turbulence near the large local gradients also suggest actively evolving, not remnant features.

On and near the Antarctic continental shelf we have frequently recorded thermohaline staircases of varying dimensions at intermediate depths. Some were of the variety generally ascribed to double-diffusive processes, e.g., cold fresh over warm salty water beneath the Antarctic Surface Water temperature minimum, or warm salty over cold fresh water below the Circumpolar Deep Water that intrudes onto the continental shelf. At other times, steps were barely discernible, or not much greater than the resolution of the instrumentation then being used. Station 217 is unlike any of the above, but graphically displays a statically stable configuration of relatively warm fresh over cold salty water. This is analogous to the homogeneous summer surface layer that overlies the temperature minimum (steps also occur at that transition), but here the stairs are more uniform and descend to greater depths.

The step structure observed here differs in an important respect from that reported, e.g., by Neal et al. [1969], under a drifting ice island in the Arctic. In that case the steps were formed by the one-dimensional process of cooling from 


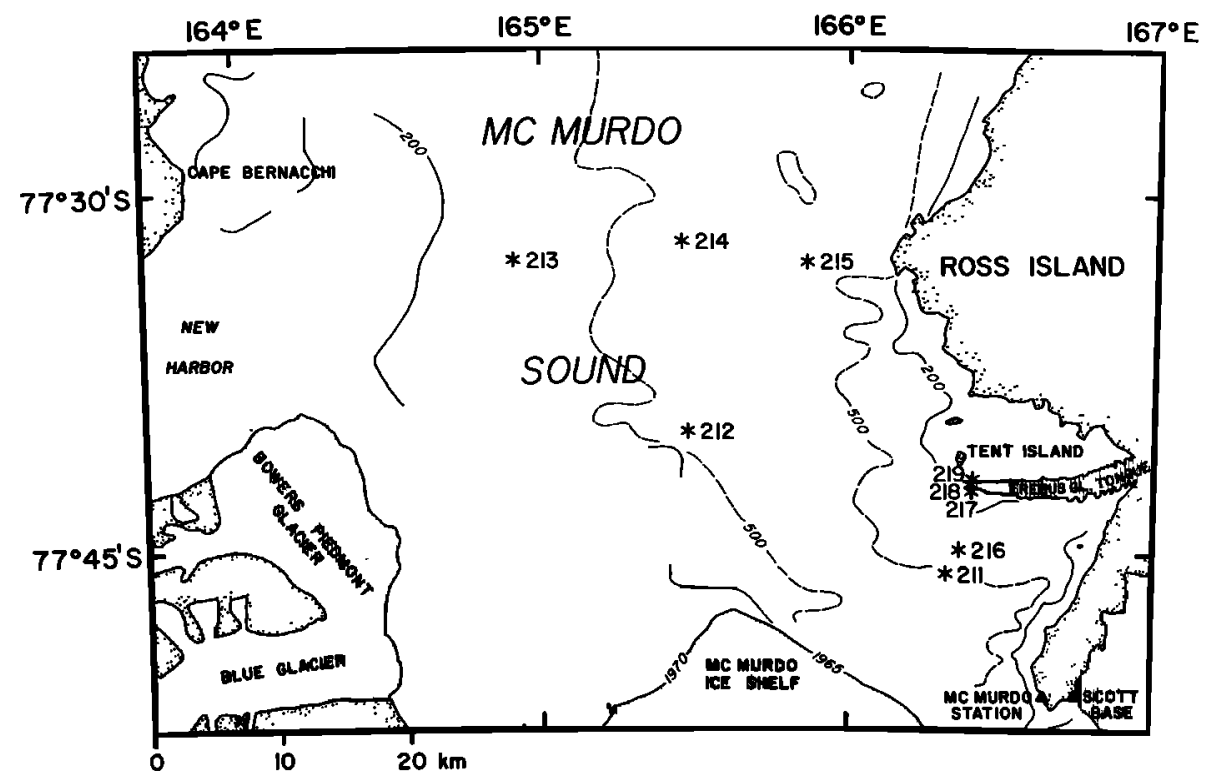

Fig. 1. Oceanographic stations (CTD 211-219) taken during February 1979 from the U.S. icebreaker Glacier in McMurdo Sound. Stations 217-219 were near the end of Erebus Glacier Tongue, which at that time projected nearly 13 km from Ross Island into the Sound. Topographic features are from the USGS map Ross Island, Antarctica, ST 57-60/6.

above, which produces a statically unstable temperature profile. In our situation the cooling is from the side and produces steps even though both temperature and salinity profiles are statically stable.

\section{The ERebus Glacier TONGUE (EGT)}

Radio echo records were obtained in January 1978 along an approximate center line of the EGT [Drewry et al., 1980]. The antenna system of four colinear dipoles mounted at $1 / 4$ wavelength beneath the starboard wing of a C-130 (Hercules) aircraft gives a radiation pattern with beam angle of $80-90^{\circ}$ foreand-aft and up to $60^{\circ}$ in the transverse direction. At a flight height of $300 \mathrm{~m}$; returns can be observed from the upper surface, the bottom of surface crevasses, the ice/water interface containing crevasse-like structures at bottom, and the ice tongue "teeth" on either edge and associated crevasses which penetrate toward the center of the ice tongue. Extensive surface crevassing near the landward end gave rise to clutter echoes which obscured returns from the base of the tongue there. Interpretation of the basal profile is thus somewhat uncertain, and our ice thickness may be in error by $\pm 15 \mathrm{~m}$. The resolution is better than this but is a function of bottom roughness and lateral continuity.

The ice thickness data indicate a two-step thinning beginning at the grounding line. The main thinning occurs at depths below about $75 \mathrm{~m}$; the outer third of the Glacier Tongue thins by $25 \mathrm{~m}$ at most. The radar basal profile shows a roughness underneath the EGT that is about the same magnitude as the thermohaline steps on station 217. Due to problems of resolution and interpretation of the echo sounding data noted above, we can only speculate at present that anomalies from an equilibrium basal profile are real and related to the thermohaline steps. Below the influence of the EGT (the grounding line is at $\approx 275 \mathrm{~m}$ ), salinity and density steps in the seawater are considerably less distinct and temperature is essentially isothermal (Figure 3).

\section{THEORY}

Recently there has been a series of investigations of the fluid dynamics of ice walls melting into surrounding water.
One set of investigations [Neshyba, 1977; Josberger, 1979] assumes little or no salinity gradient in the surrounding water and focuses upon the boundary layer near the ice. The other work [Huppert and Turner, 1978, 1980; Huppert and Josberger, 1980] concentrates on the influences of vertical salinity (density) stratification.

Neshyba [1977] conjectured that adjacent to a melting ice wall there will be a turbulent boundary layer which entrains water from the environment. Considering a two-layer model of the ocean and using the criterion that entrainment is just sufficient to ensure that the density in the boundary layer at the surface equals the density of the upper layer, Neshyba calculates an entrainment ratio for the Weddell Sea of 60 to 1 (that is, for each unit of meltwater in the boundary layer there is entrained 60 units of surrounding water). Subsequently, Josberger and Neshyba [1980] placed concentrated rhodamine dye at 14-18 $\mathrm{m}$ depths along the sloping wall of an Arctic iceberg and found that it rose at $\approx 7 \mathrm{~cm} \mathrm{~s}^{-1}$ to the surface next to the ice.

Greisman [1979] considered the thermodynamics involved in the melting process and calculated the amount of heat required from the turbulent, entraining boundary layer to melt the ice. This lead to a minimum entrainment ratio $\varepsilon$ given by

$$
\varepsilon=L \rho_{\omega} / C_{p} \Delta T \rho_{\infty}
$$

where $L$ is the latent heat of fusion of ice, $\rho_{\omega}$ the density of fresh water, $C_{p}$ the specific heat of seawater, $\Delta T$ the temperature excess of the far-field water over that at the ice wall, and $\rho_{\infty}$ the density of the far field, which is assumed to be independent of depth. By considering the mixture of fresh water and far-field water in the boundary layer, it followed that the density difference $\Delta \rho$ between the far field and the boundary layer is given by

$$
\Delta \rho=\left(\rho_{\infty}-\rho_{\omega}\right) /(1+\varepsilon)
$$

If the far field is vertically stratified, Greisman stated that the water in the boundary layer flows upward only by an amount

$$
h=\Delta \rho / \frac{d \rho}{d z}
$$




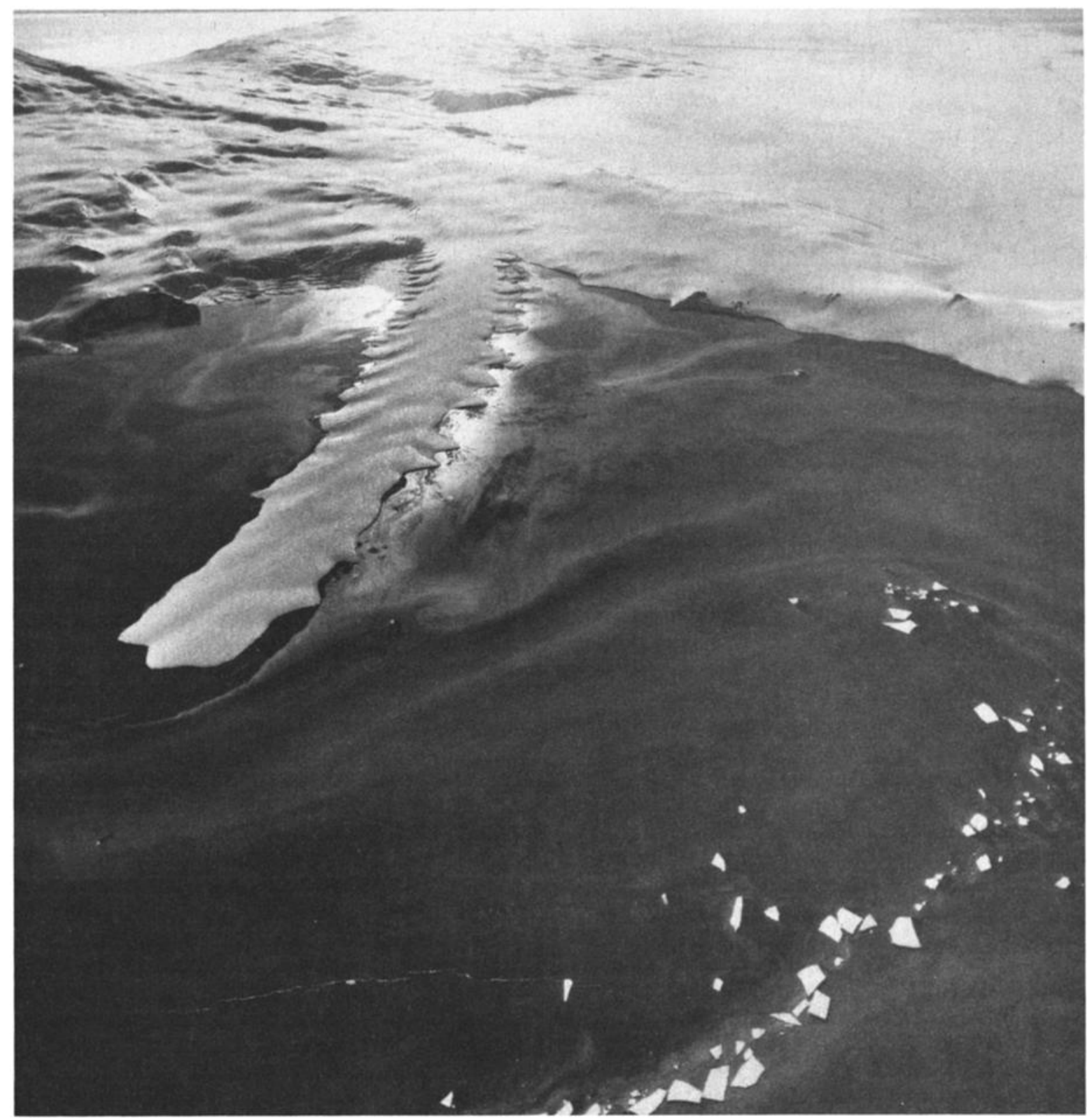

Fig. 2a. Aerial oblique photograph of Erebus Glacier Tongue at a time $(\approx 2100 \mathrm{Z}$, February 18,1965$)$ when little solid pack ice remained in Erebus Bay. The Ice Tongue had increased about $2 \mathrm{~km}$ in length by the time of the CTD stations reported here. The sea surface patterns and drifting ice suggest flow toward the Glacier Tongue from the south.

where $d \rho / d z$ is the vertical density gradient before it loses its relative buoyancy and turns inward to form a series of layers. Greisman does not suggest a mechanism by which the layers could be formed.

Josberger conducted a series of carefully considered and analyzed experiments using vertical ice walls $1.2 \mathrm{~m}$ high melting into water at temperatures from $-1^{\circ} \mathrm{C}$ to $+20^{\circ} \mathrm{C}$ at a uniform salinity of around $33 \%$. Above a very short laminar boundary layer with an upward-flowing inner layer and a downward-flowing outer layer, Josberger observed a turbulent boundary layer of solely upward motion. The width of this layer increased as $z^{1 / 4}$, where $z$ is the vertical length measured from the bottom of the turbulent layer. This is in agreement with a similarity solution obtained by Josberger from the approximate Navier-Stokes equations of motion.

In the presence of a vertical salinity gradient, flow in the vi- cinity of the ice is altogether different [Huppert and Turner, 1980]. Next to the ice there is a thin upward-flowing layer of meltwater, beyond which there is a thicker, turbulent, downward-flowing layer. This outer turbulent layer entrains meltwater from the inner boundary layer. Because of the increase in salinity, and thereby density, with depth, the water in this cooled outer layer reaches a level of neutral buoyancy and flows away from the ice in a series of nearly horizontal layers. The laboratory experiments of Huppert and Turner [1978, 1980] and Huppert and Josberger [1980] and their related analyses suggest that the layer scale is well represented by

$$
h=0.65\left[\rho\left(T_{f}, \bar{S}_{\infty}\right)-\rho\left(T_{\infty}, S_{\infty}\right)\right] / \frac{d \rho_{s}}{d z}
$$

where $\rho(T, S)$ is the density as a function of temperature and 


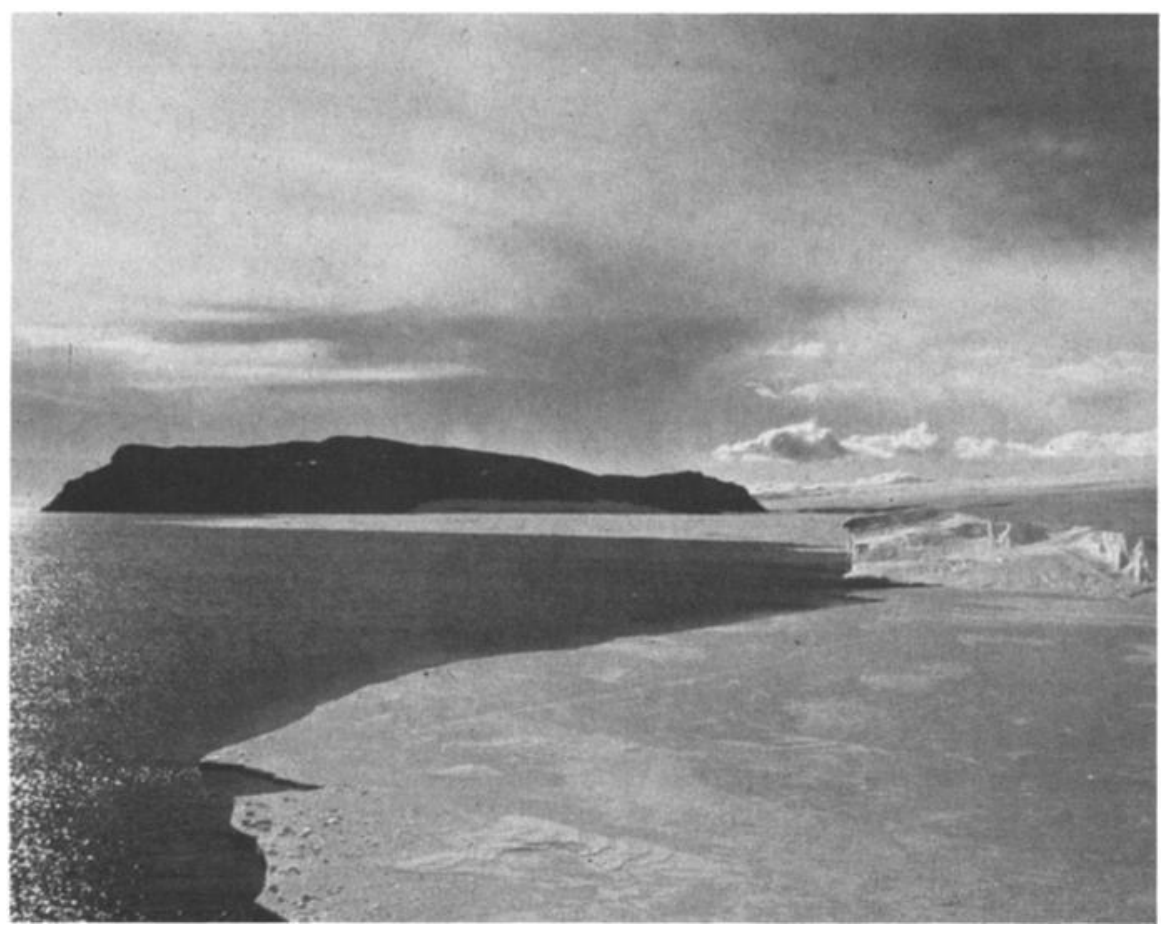

Fig. 2b. A northward view on February 15, 1979 from the icebreaker Glacier at a position slightly south of station 217. At this time only the western terminus of the Erebus Glacier Tongue protruded at right center from the sea ice. Tent Island is in the left center background, and the lower slope of Mt. Erebus appears in the right distance.

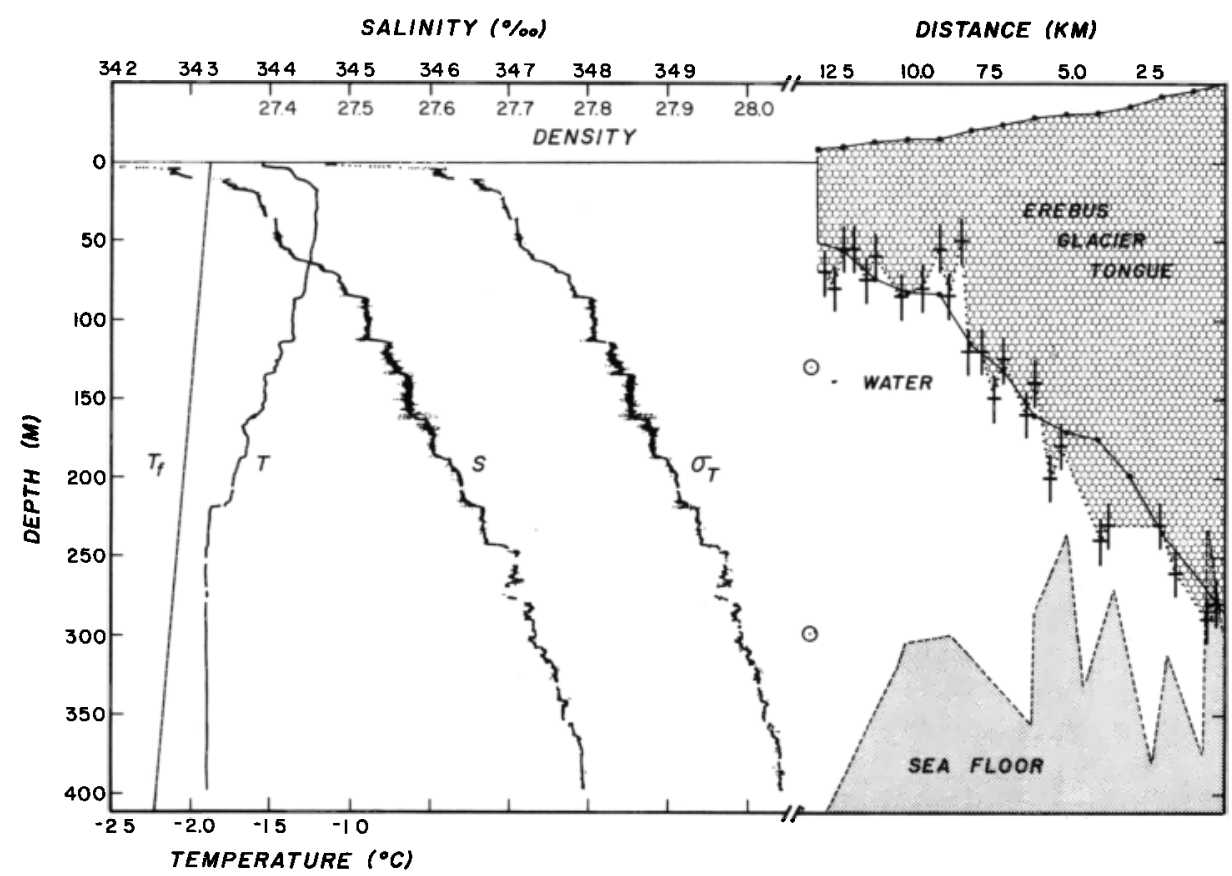

Fig. 3. (Left) Temperature $T$, salinity $S$, and density $\sigma_{t}$ profiles from Glacier station 217 , located a few hundred meters south of the western terminus of Erebus Glacier Tongue (EGT). The in situ freezing point $\left(T_{j}\right)$ is after Fujino et al. [1974]. (Upper right) A vertical section along the EGT center line. The upper surface of the floating glacier is defined at $1 \mathrm{~km}$ intervals ( $\pm 100 \mathrm{~m}$ ) to $\pm 2 \mathrm{~m}$ in the vertical. The equilibrium basal profile (dash-dot line) is calculated for free flotation of a slab of mean density $0.87 \mathrm{Mg} \mathrm{m}^{-3}$. The January 1978 radar basal profile (dotted line) has a vertical resolution of $\pm 15 \mathrm{~m}$ as shown by the error bars. North and south edges of the EGT are approximately $40 \%$ thinner than the center line profile. (Lower right) Dashed line connects line soundings of the sea floor north and south of the EGT. Circled dots are bottom depths on CTD stations 218, and 219. The EGT moves off Ross Island into water that is 225-275 m deep. The irregular sea floor beneath the EGT continues for at least another $5 \mathrm{~km}$ west of its terminus (DMA chart 29322, Cape Royds to Hut Point). 
TABLE 1. Computed and Observed Vertical Step Dimensions

\begin{tabular}{|c|c|c|c|c|c|c|c|c|c|}
\hline \multirow[b]{2}{*}{ Depth, m } & \multirow[b]{2}{*}{$s, \%$} & \multirow[b]{2}{*}{$T,{ }^{\circ} \mathrm{C}$} & \multirow[b]{2}{*}{$T_{f},{ }^{\circ} \mathrm{C}$} & \multirow[b]{2}{*}{$\Delta T,{ }^{\circ} \mathrm{C}$} & \multirow[b]{2}{*}{$\rho$} & \multirow[b]{2}{*}{$\rho_{f}$} & \multirow[b]{2}{*}{$\Delta \rho \times 10^{7}$} & \multicolumn{2}{|c|}{$h(m)$} \\
\hline & & & & & & & & Eq. (4) & Obs. \\
\hline $\begin{array}{r}0 \\
50 \\
100 \\
150 \\
200 \\
250 \\
300 \\
350 \\
400\end{array}$ & $\begin{array}{l}34.117 \\
34.412 \\
34.523 \\
34.572 \\
34.637 \\
34.710 \\
34.734 \\
34.768 \\
34.795\end{array}$ & $\begin{array}{l}-1.53 \\
-1.23 \\
-1.35 \\
-1.52 \\
-1.73 \\
-1.90 \\
-1.90 \\
-1.90 \\
-1.89\end{array}$ & $\begin{array}{l}-1.87 \\
-1.92 \\
-1.97 \\
-2.01 \\
-2.05 \\
-2.09 \\
-2.13 \\
-2.17 \\
-2.21\end{array}$ & $\begin{array}{l}0.34 \\
0.69 \\
0.62 \\
0.49 \\
0.32 \\
0.19 \\
0.23 \\
0.27 \\
0.32\end{array}$ & $\begin{array}{l}1.0273505 \\
1.0278203 \\
1.0281551 \\
1.0284421 \\
1.0287431 \\
1.0290492 \\
1.0293103 \\
1.0295791 \\
1.0298415\end{array}$ & $\begin{array}{l}1.0273584 \\
1.0278396 \\
1.0281732 \\
1.0284568 \\
1.0287530 \\
1.0290552 \\
1.0293180 \\
1.0295886 \\
1.0298534\end{array}$ & $\begin{array}{r}79 \\
193 \\
181 \\
147 \\
98 \\
60 \\
77 \\
95 \\
119\end{array}$ & $\begin{array}{r}6 \\
14 \\
13 \\
11 \\
7 \\
4 \\
6 \\
7 \\
9\end{array}$ & $\begin{array}{r}5 \\
17 \\
27 \\
29 \\
31 \\
34 \\
28 \\
15 \\
35\end{array}$ \\
\hline
\end{tabular}

Salinity and temperature from station 217 , in situ freezing temperature $T_{f}$ from Fujino et al. [1974].

Density $\left(\rho\right.$ and $\left.\rho_{f}\right)$ after Gebhart and Molendorf [1977]. Layer thickness $h$ is from equation (4) and from the layer at each $50 \mathrm{~m}$ interval on station 217.

salinity, $T_{f}$ is the freezing point of water at the mean far-field salinity $\bar{S}_{\infty}$, and $d \rho_{s} / d z$ is the vertical density gradient due to salt. From the Huppert and Turner experiments it appears that the factor 0.65 holds over a large range of scales, or Grashof numbers, and this is consistent with the numerical integrations of Chen et al. [1971] and Chen [1974]. The experiments indicated that the layer thicknesses were uniform with depth and the mean far-field salinity was needed in (4), as indicated, although the theory as so far developed suggests that the layer thickness $h$ might respond to the local rather than the mean far-field salinity.

\section{STATION 217}

Appearance of the best-developed step structure on a station close to the EGT suggested that its formation might result from melting of ice into the salinity gradient. The validity of this hypothesis can be examined quantitatively by comparing the observed layer thicknesses with those predicted by (4).

The vertical density gradient due to salt can be evaluated by fitting a line of constant slope through the salinity profile of station 217. Orienting the line to connect a salinity of $34.523 \%$ at $100 \mathrm{~m}$ and one of $34.637 \%$ at $200 \mathrm{~m}$, we determine that $d S_{\infty} / d z=1.1 \times 10^{-3} \%_{0} \mathrm{~m}^{-1}$ and hence that $\rho_{0}{ }^{-1} d \rho_{s} / d z=$ $8.8 \times 10^{-7} \mathrm{~m}^{-1}$, where $\rho_{0}$ is the mean density $\left(\approx 10^{3} \mathrm{~kg} \mathrm{~m}^{-3}\right)$. The results of applying (4) at nine representative station 217 depths, salinities and temperatures are shown in Table 1 . The freezing point temperature as a function of salinity and pressure was calculated from the relationship in Fujino et al. [1974], after correcting the sign of their pressure term. The density as a function of temperature and salinity was evaluated by the formulation of Gebhart and Molendorf [1977], and the parameters of station 217 were taken to represent the far-field values.

Application of (4) to station 217 results in predicted layer thicknesses of 4-14 m, with layers in the 50-150 m interval about twice as thick as those at the surface and below $150 \mathrm{~m}$. Aside from the surface and bottom boundaries, the layer thickness in this case is, more simply, proportional to the driving temperature, $\Delta T=T-T_{f}$ (Figure 4; see also Greisman [1979] and Neshyba and Josberger [1980]).

The major steps observed on station 217 range from 5 to 35 $\mathrm{m}$ thick, averaging $17 \mathrm{~m}$. The thickness of the layer nearest each $50 \mathrm{~m}$ depth increment is shown in Table 1. Agreement between theory and observation is best in the upper water column as might be expected. The tank experiments were done with vertical ice walls, and the EGT terminus is more nearly vertical in the top 50-75 $\mathrm{m}$ (Figure 3). There are small steps within larger ones, particularly below $250 \mathrm{~m}$, but in general below the Glacier snout the primary steps are thicker than predicted by a factor of 2 or more. Assuming that our formulation is essentially correct and that we should focus upon the major steps, what can account for the discrepancy between predicted and observed layer thickness?

The equilibrium bottom profile of the EGT more nearly resembles a sloping ceiling than a vertical wall. The vertical scale of Figure 3 exaggerates the thickness gradient, which is at most about 1:40. We (H.E.H.) found that the flow due to an ice block sloping $45^{\circ}$ in the laboratory tank was not essentially different from that produced by a vertical wall. This is because the scales are determined by the vertical displacement induced by cooling from the side and not the angle at which the cooling takes place. However, there may be a critical slope beyond which relatively less boundary layer meltwater rises and more is entrained into the layered structure.

Another difference between the field and laboratory measurements is that, with increasing depth in the water column, the CTD records are further from the presumed source of the steps. Since the steps (layers) are statically stable, vertical mixing within a layer will be greater than mixing between layers. Turbulent exchange of water across the discontinuities might result in more energetic layers growing at the expense of adjacent, less-energetic ones. At each $50 \mathrm{~m}$ depth interval down to the grounding line, observed layer thickness on station 217 is

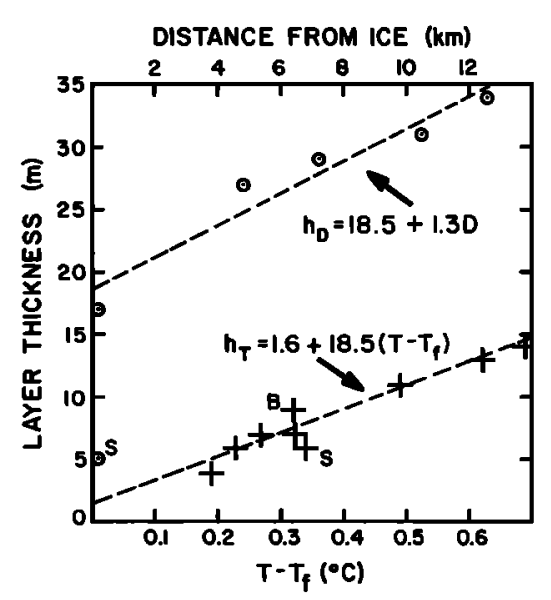

Fig. 4. (Lower) Computed layer thickness (equation (4)) related to difference between in situ temperature $T$ and freezing temperature $T_{f}$. (Upper) Observed layer thickness (station 217) related to horizontal distance from ice (Figure 3 ). $S$ and $B$ refer to sea surface and bottom points. 
directly proportional to horizontal distance from the EGT (Figure 4). The line intercept is only $4 \mathrm{~m}$ greater than predicted by (4) and suggests a vertical step growth of $1.3 \mathrm{~m} \mathrm{~km}^{-1}$ from the ice.

Since the steps on station 217 were not coherent over a wide area, we could infer that they coalesce fairly rapidly into thicker layers. We have observed $50 \mathrm{~m}$ and thicker homogeneous layers above and within the high-salinity shelf water in the Ross Sea. The thickest layers on station 217 were near the sea floor, where interactions could be expected between currents and bottom irregularities. There are shoals at several depths near the EGT (Figure 3), and internal waves generated by tidal flow around these features [e.g., Farmer and Smith, 1980] could provide an energy source for mixing within the layers.

In the laboratory experiments of Huppert and Turner [1978], ridging of the ice block was caused by differential melting associated with the layered convection. If the lower surface of the Glacier Tongue also has a stepped structure, it could result from the convective cells or from internal waves that propagate at the ocean density steps. Waves are particularly effective in eroding ice at the sea surface [Martin et al., 1978]. Greater turbulence where the internal waves impinge on the ice might increase the melting rate.

There are several reports of layered structure near melting glacial ice in the Arctic. Greisman [1979] refers to $10 \mathrm{~m}$ convective cells in d'Iberville Fiord, Northwest Territories, where the glacier wall-seawater temperature difference $\left(0.3^{\circ} \mathrm{C}\right)$ is comparable to our EGT case. However, we cannot readily apply his relationship, which contains the unknown entrainment ratio $\varepsilon$, to these Antarctic data. Josberger and Neshyba [1980] have reported the formation of $5 \mathrm{~m}$ isothermal layers near an iceberg grounded in $90 \mathrm{~m}$ of water, but in a density gradient several times that of our station 217.

\section{Salt, Heat, and Mass Flux NEAR THE GLACIER TONGUE}

The ice depth data and stress/strain relationships indicate that the EGT is floating throughout its length [Holdsworth, 1974]. Due to its continuous westward movement, the EGT increased in length by about $4750 \mathrm{~m}$ between 1947 and 1979 (Holdsworth [1974], updated by the satellite-navigated ship position of the icebreaker Glacier during occupation of station $218,77^{\circ} 42.3^{\prime} \mathrm{S}, 166^{\circ} 23.9^{\prime} \mathrm{E}$ ). Assuming only minor calving at the terminus during that time results in a rate of advance of about $150 \mathrm{~m} \mathrm{yr}^{-1}$. Allowing for integrated horizontal stretching of the ice beginning at the grounding line, then ice at the present location of the terminus has been suspended in seawater that is above the in situ freezing point for about 85 years. The data show the EGT to be thinning by $\approx 280 \mathrm{~m}$ between the grounding line and western terminus. Allowing for creep thinning [Weertman, 1957], approximately $120 \mathrm{~m}$ would be due to basal melting. This would correspond to a melt rate of about $1.4 \mathrm{~m} \mathrm{yr}^{-1}$.

Is melting at the base of the EGT sufficient to generate the thermohaline staircase shown in Figure 3? We assume that a salt deficit can be defined by the area between the salinity/ depth profile and a line tangent to the right-hand side of the salinity/depth profile in the $100-200 \mathrm{~m}$ interval. Taking $0.02 \%$ as a typical salinity discontinuity, we find that each 20 $\mathrm{m}$ step in a $\mathrm{cm}^{2}$ water column represents a $0.02 \mathrm{~g}$ salt deficit, which in turn corresponds to the addition of about $0.6 \mathrm{~cm}^{3}$ of fresh water. The EGT is now melting into a $200 \mathrm{~m}$ thick water column and would thus need to add a minimum $6 \mathrm{~cm}^{3}$ of fresh water per $\mathrm{cm}^{2}$ of basal surface to produce steps of the size observed on station 217.

This salinity change defines a rough area over which such melt-induced steps could be distributed each year. For example, if the basal melt rate of the EGT were between 0.3 and $3.0 \mathrm{~m} \mathrm{yr}^{-1}$, then steps of the dimensions observed on station 217 could be generated over an area of $75-750 \mathrm{~km}^{2}$, or $5-50$ times the basal area of the EGT. The corresponding residence time for the station 217 water column under the EGT would then be 0.2 to $0.02 \mathrm{yr}$. An area of $350 \mathrm{~km}^{2}$ and residence time of $0.04 \mathrm{yr}$ would apply to the $1.4 \mathrm{~m} \mathrm{yr}^{-1}$ melt rate estimated above.

Is sufficient heat available below the sea surface to melt 1.4 $\mathrm{m} \mathrm{yr}^{-1}$ off the base of the Erebus Glacier Tongue? The water column between 75 and $250 \mathrm{~m}$ ranges from about $0.7^{\circ}$ to $0.2^{\circ} \mathrm{C}$ above the in situ freezing temperature (Figure 3). From year-round temperature measurements to $550 \mathrm{~m}$ depths [Tressler and Ommundsen, 1962] we would expect that most of the subsurface water column in McMurdo Sound also remains above the in situ freezing point during winter. Suppose the annual average temperature above freezing were only $0.1^{\circ} \mathrm{C}$, about the mean difference between $T_{f}$ and a line connecting $T_{f}$ at the surface with the coldest portion of $T$ at about $250 \mathrm{~m}$ (Figure 3). Then a $200 \mathrm{~m}$ thick water column exchanged 25 times $\mathrm{yr}^{-1}$ (reciprocal of the $0.04 \mathrm{yr}$ residence time) would require only $30 \%$ of that heat to melt the $1.4 \mathrm{~m}$ of ice. Thus there is sufficient heat in the water column to melt the ice and adequate meltwater to produce the observed salinity steps in a reasonable residence time. The effective transfer of heat from water to ice depends upon mixing coefficients and boundary layer dynamics, a discussion of which is beyond the scope of these data.

Tidal currents could move a series of steps around the EGT region, but little is known about the flow at this location. The sailing directions for Antarctica [U.S. Hydrographic Office, 1960] indicate a northwestward surface current as strong as 3 knots nearby, but also note that this Cape Armitage current has been observed to set southward under certain conditions. One of us (G.H.) drilled sounding holes through the sea ice north and south of the EGT. Water (and fish) upwelled through several of the holes on the south side, suggesting a flow from that direction in the near-surface layer. One could also infer a current from the south by the sea surface and drift ice patterns in Fig. 2b. During station 217 the wind was from $96^{\circ}$ at 7-15 knots which would have induced a surface flow toward the south and away from the pack ice edge.

Subsurface current measurements made at various times and locations in McMurdo Sound, usually for brief periods, were summarized by Heath [1977]. Within a regime of high variability and strong diurnal tides, he discerned a pattern of mean drift toward the south in the middle of the Sound and to the north on the eastern and western sides, with the greatest velocities at mid-depths. The current velocities for depths below $50 \mathrm{~m}$ in Heath's Table 4 average about $10 \mathrm{~cm} \mathrm{~s}^{-1}$. Moving at this speed, a $15 \mathrm{~km}^{2}$ water mass would remain beneath the EGT for only 3 hours rather than the 2 weeks implied by our 0.04 yr residence time. Once the tidal signal is filtered out however, residual drift will be considerably less than $10 \mathrm{~cm}$ $\mathrm{s}^{-1}$. In any case, only first-order estimates can be made from these limited observations.

There is evidence for some freezing at shallower levels on the Erebus Glacier Tongue. The radar basal profile (Figure 3) 


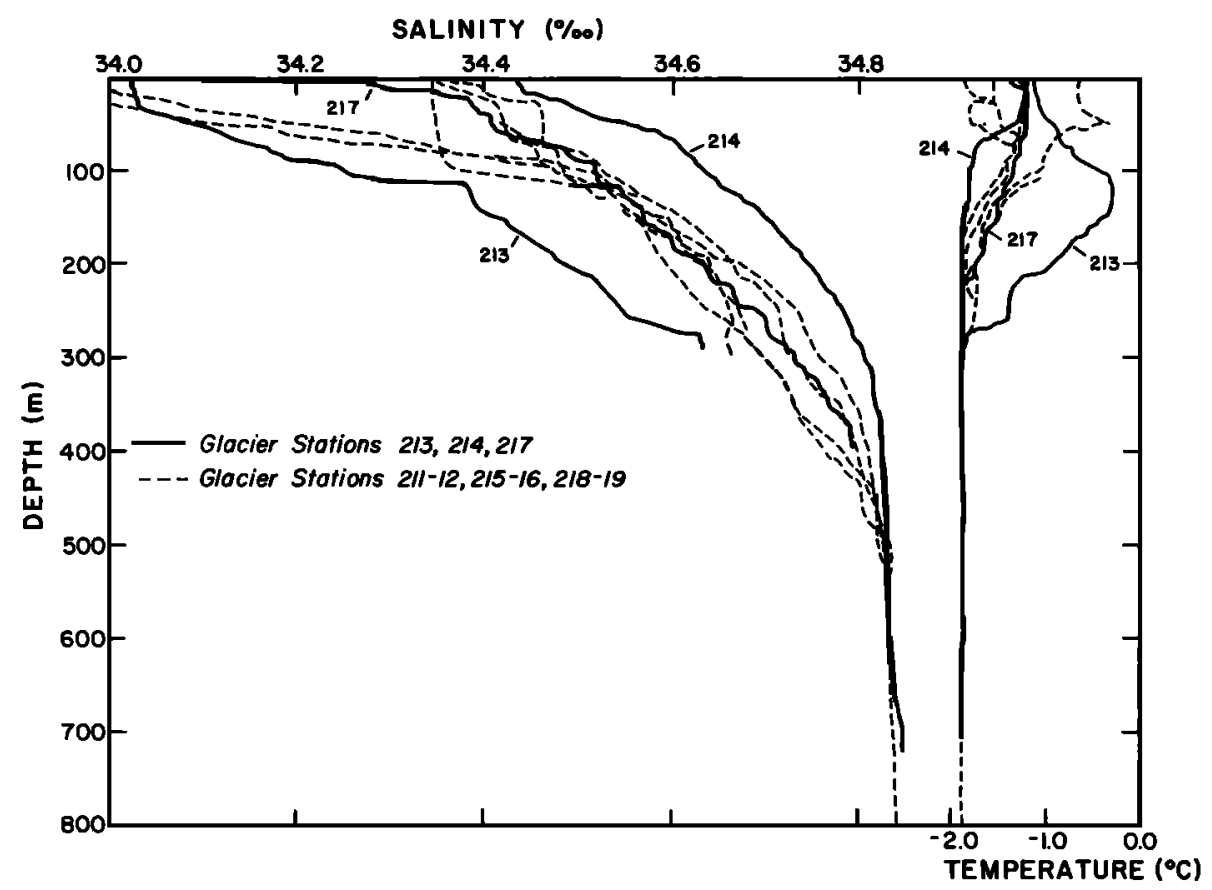

Fig. 5. Composite salinity/depth and temperature/depth profiles for Glacier stations 211-219 in southern McMurdo Sound, Antarctica. The station locations are shown in Figure 1.

shows a roughly constant thickness over the outer $4 \mathrm{~km}$ of the EGT, while surface elevations decrease toward the end. This implies an increasing average ice column density toward the end, which could result from the presence of higher-density sea ice. Summer is brief in the Antarctic, and above $75 \mathrm{~m}$ the EGT is well within the range of sea surface heat flux. Further, the EGT internal temperature gradient is likely to be steeper near the thinner end, which could facilitate winter freezing in that sector. From McMurdo Sound winter observations, Loewe [1961] has reported that ice blocks lowered to $47 \mathrm{~m}$ grew in size, and Dayton et al. [1969] found that ice platelets accumulate on bottom and on suspended lines to depths of 33 $\mathrm{m}$. However, it does not seem possible that the thermohaline structure we measured resulted from freezing. Continued melting and thinning would be expected from the summer water column temperature profile. Any layered structure that resulted from freezing of seawater deep beneath the ice shelves would probably be slight due to the low freezing rate there and not persist for long in the relatively active current regime [Jacobs et al., 1979a].

\section{REgIONAL OCEANOGRAPHY}

Subsurface melting of glacial ice influences the regional water column well beyond the point where discrete steps can be followed. Figure 5 is a composite of the vertical CTD profiles for stations 211-219 in McMurdo Sound. The data fall into three separate regimes in the depth interval corresponding to that of the EGT base. Station 214 with the highest salinity and lowest temperature is typical of the high-salinity shelf water that predominates in the southwest sector of the Ross Sea [ $\mathrm{Ja}$ cobs et al., 1970a]. Station 213 has the lowest salinity and highest temperature, resembling several other stations on this part of the continental shelf that display a warm core [Car and Codispoti, 1968, station 9; Bourkland, 1969, station 5; Jacobs et $a l ., 1970 b$, station 721$]$. The type 213 station appears less common than the type 214 , and mixing of the two would tend to- ward the intermediate station 217 characteristics. The remaining stations cluster around 217 in the $100-400 \mathrm{~m}$ depth range, and their spacing provides a rough estimate of the area influenced by meltwater from the Erebus Glacier Tongue. An ellipse that includes all stations but 213 and 214 covers nearly $1000 \mathrm{~km}^{2}$, more than twice the area projected above. However, we cannot readily estimate the contributions that might be made by other glacial ice in the vicinity nor the residence time of meltwater in McMurdo Sound.

Salinities of the stations grouped around station 217 converge in the vicinity of $120 \mathrm{~m}$ (Fig. 5). That depth corresponds to the temperature maximum on station 213 and probably marks the lower limit of recent sea surface processes in this area. The warmer water on stations like 213 is ultimately derived from distant Circumpolar Deep Water, the primary heat source for glacial melting [Jacobs et al., 1979a]. Melting should be greatest at intermediate depths and density horizons in common with the Circumpolar Deep Water where it intrudes onto the continental shelf. For example, the warmest water on station 222 at the Ross Sea continental margin $\left(75^{\circ} 18^{\prime} \mathrm{S}, 175^{\circ} 35^{\prime} \mathrm{W}\right.$ ) had a density similar to that at $120 \mathrm{~m}$ on station 217.

Salinities of all deeper stations in Figure 5 converge again near $500 \mathrm{~m}$, possibly marking the lower limit of glacial melting in the Ross Sea. Below $500 \mathrm{~m}$ the water column may be dominated by the effects of freezing at the base of the Ross Ice Shelf perimeter [Zotikov et al., 1980], on the walls of bottom crevasses in the floating glacial ice [Barrett, 1975; Clough et al., 1975] and from deep convection during winter pack ice formation and in polynyas along the Victoria Land coast.

\section{Discussion}

These CTD measurements demonstrate the melt-driven structuring of subsurface circulation into convection cells of limited vertical extent. This extends laboratory and Northern Hemisphere observations of layering near melting ice to Ant- 
arctic field conditions where a weaker density stratification prevails. The mean layer thickness is near $17 \mathrm{~m}$, about an order of magnitude less than estimated for the Antarctic by Neshyba and Josberger [1980]. Relatively little of the glacial meltwater may reach the sea surface, thereby limiting effects on nutrient cycles and crystal formation in upwelling water [Neshyba, 1977; Foldvik and Kvinge, 1974].

Separation of the water column into discrete density levels should facilitate differential advection or diffusion of properties within layers and retard vertical motions across the layers. This has implications for the way in which important glacial ice tracers, e.g., the $\mathrm{O}^{18} / \mathrm{O}^{16}$ ratio [Weiss et al., 1979], will be injected into the ocean. Individual steps may not persist unaltered very far from the source, but we have recorded similar, less distinct structures near the Ross Ice Shelf and elsewhere in the Ross Sea. If melt-driven stratification is widespread on the Antarctic continental shelves, it could contribute throughout the year to a circulation pattern more aligned with isopycnals than heretofore might have been realized.

The existence of the long and narrow Erebus Glacier Tongue over several decades illustrates some aspects of basal melting versus vertical sidewall melting for the attached Antarctic ice shelves and glaciers. Most recent analyses of iceberg melting in the sea have concentrated upon the sidewalls where melting per unit area may be more efficient than at the base. Morgan and Budd [1978] computed comparable melt rates for the sides and bases of icebergs however, finding the rate to be linearly proportional to water temperature and ranging from a few $\mathrm{m} \mathrm{yr}^{-1}$ in below-zero water to about $100 \mathrm{~m} \mathrm{yr}^{-1}$ in $4-6^{\circ} \mathrm{C}$ water near the Polar Front (Antarctic Convergence). Ignoring horizontal spreading and calving, net melting of the EGT sidewalls could not exceed $2 \mathrm{~m} \mathrm{yr}^{-1}$ without altering the overall dimensions of the Glacier. For comparison, a current velocity of $10 \mathrm{~cm} \mathrm{~s}^{-1}$ along the $12.8 \mathrm{~km}$ EGT length, substituted into equation (8) of Weeks and Campbell [1973], gives a melt rate of $0.5 \mathrm{~m} \mathrm{yr}^{-1}$ for each $0.1^{\circ} \mathrm{C}$ increment of seawater temperature above the freezing point. Jacobs et al. [1979a] estimated somewhat lower values for net melting between points under the Ross Ice Shelf.

Shallow melting will be curtailed in winter when the sea surface freezes. Deep melting will continue in winter [Robin, 1979] due to the effect of pressure on the melting point $\left(T_{f}\right.$ in Figure 3 ) and to the lateral, subsurface inflow of warmer water as noted above. The Antarctic ice shelves and glaciers expose to seawater a basal area more than 2 orders of magnitude greater than the area of their vertical walls. In the Ross Sea and other continental margin areas we have investigated, there appears to be a supply of heat from the Circumpolar Deep Water to the sub-ice regime. Thus basal melting should have greater oceanographic and glaciological impacts than wall melting even if basal mass flux rates are somewhat lower.

In spite of adequate nutrients in the Antarctic Surface Water, phytoplankton growth is limited there by the short season of sufficient sunlight and by a surface layer that can be deeply mixed by winds and sea ice formation. In this nearly homogeneous environment, the melting of pack and glacial ice is no doubt biologically important. Enhanced stability of the shallower layers should limit the depth of mechanical mixing, thereby retaining a greater percentage of viable phytoplankton within the euphotic zone. Finenko [1978] notes the importance of this process in the Arctic and other regions. Particulates and biological forms could accumulate at the density discontinuities. These factors may account in part for observa- tions of increased plant and animal life near the ice [e.g., $\mathrm{Ja}$ cobs et al., 1979b; Ainley and Jacobs, 1981].

Acknowledgments. This work was supported by NSF grants DPP 77-22209 and DPP 79-18674 to Columbia University; by the Ministry of Defence (Procurement Executive); and by U.K. Natural Environment Research Council grant GR3/2291 to Scott Polar Research Institute. Logistic support was provided by the National Science Foundation Division of Polar Programs. We have been ably assisted in various aspects of this study by J. Szelag, A. Amos, D. Woodroffe, P. Woodroffe, A. Gordon, E. Jankowski, and H. Steed. The photographs were taken by the U.S. Navy (Figure $2 a$ ) and by S. Patla (Figure $2 b$ ). Several colleagues made helpful suggestions on the manuscript. Typing and drafting were done by A. Baker, K. O'Neill, and $M$. Turner. LDGO contribution 3170.

\section{REFERENCES}

Ainley, D. G., and S. S. Jacobs, Seabird affinities for ocean and ice boundaries in the Antarctic, Deep Sea Res., in press, 1981.

Barrett, P. J., Seawater near the head of the Ross Ice Shelf, Nature, 256, 390-392, 1975.

Bourkland, M., Oceanographic cruise summary, Ross Sea, Antarctica, Feb. and Mar. 1969, Inform. Rep. 69-75, 11 pp., Naval Oceanogr. Office, Washington, D. C., 1969.

Car, M., and L. A. Codispoti, Oceanographic cruise summary, Ross Sea, Antarctica, Feb. 1968, Inform. Rep. 68-64, 21 pp., Naval Oceanogr. Office, Washington, D. C., 1968.

Chen, C. F., Onset of cellular convection in a salinity gradient due to a lateral temperature gradient, J. Fluid Mech., 63, 563-576, 1974.

Chen, C. F., D. G. Briggs, and W. A. Wirtz, Stability of thermal convection in a salinity gradient due to lateral heating, Int. J. Heat Mass Transfer, 14, 57-65, 1971.

Clough, J. W., K. C. Jezek, and J. D. Robertson, RISP drill site survey, Antarct. J. U.S., 10, 148-149, 1975.

Dayton, P. K., G. A. Robilliard, and A. L. Devries, Anchor ice formation in McMurdo Sound, Antarctica, and its biological effects, Science, 163, 273-274, 1969.

Drewry, D. J., P. T. Meldrum, and E. Jankowski, Radio echo sounding of the Antarctic ice sheet, 1978-79, Polar Rec., 20, 43-51, 1980.

Farmer, D. M., and J. D. Smith, Tidal interaction of stratified flow with a sill in Knight Inlet, Deep Sea Res., 27A, 239-254, 1980.

Finenko, Z. Z., Production in plant populations, in Marine Ecology, vol. IV, chap. 2, Dynamics, edited by 0 . Kinne, pp. 13-87, John Wiley, New York, 1978.

Foldvik, A., and T. Kvinge, Conditional instability of sea water at the freezing point, Deep Sea Res., 21, 169-174, 1974.

Fujino, K., E. L. Lewis, and R. G. Perkin, The freezing point of seawater at pressures up to 100 bars, J. Geophys. Res., 79, 1792-1797, 1974.

Gebhart, B., and J. C. Molendorf, A new density relationship for pure and saline water, Deep Sea Res., 24(9), 831-848, 1977.

Greisman, P., On upwelling driven by the melt of ice shelves and tidewater glaciers, Deep Sea Res., 26, 1051-1065, 1979.

Heath, R., Circulation across the ice shelf edge in McMurdo Sound, Antarctica, in Polar Oceans, edited by M. Dunbar, pp. 129-149, Arctic Institute of North America, Calgary, Alberta, 1977.

Holdsworth, G., Erebus Glacier Tongue, McMurdo Sound, Antarctica, J. Glaciol., 13(67), 27-35, 1974.

Huppert, H. E., and E. G. Josberger, The melting of ice in cold stratified water, J. Phys. Oceanogr., 10, 953-960, 1980.

Huppert, H. E., and J. S. Tumer, On melting icebergs, Nature, 27I, 46-48, 1978.

Huppert, H. E., and J. S. Turner, Ice blocks melting into a salinity gradient, J. Fluid Mech, 100, 367-384, 1980.

Jacobs, S. S., A. F. Amos, and P. M. Bruchhausen, Ross Sea oceanography and Antarctic Bottom Water formation, Deep Sea Res., 17, 935-962, 1970a.

Jacobs, S. S., P. M. Bruchhausen, and E. B. Bauer, Eltanin Reports, Cruises 32-36, 1968, Hydrographic Stations, Bottom Photographs, Current Measurements, Tech. Rep. I-CM-1-70, 460 pp., LamontDoherty Geological Observatory, Palisades, New York, $1970 b$.

Jacobs, S. S., A. L. Gordon, and J. L. Ardai, Circulation and melting beneath the Ross Ice Shelf, Science, 203, 439-442, 1979a.

Jacobs, S. S., A. L. Gordon, and A. F. Amos, Effect of glacial ice melting on the Antarctic Surface Water, Nature, 277, 469-471, $1979 b$. 
Josberger, E. G., Laminar and turbulent boundary layers adjacent to melting vertical ice walls in salt water, Ph.D. thesis, Dep. of Oceanogr., Univ. of Washington, Seattle, 1979.

Josberger, E. G., and S. Neshyba, Iceberg melt-driven convection inferred from field measurements of temperature, Annals Glaciol., 1 , 113-117, 1981.

Loewe, F., On melting of fresh-water ice in sea water, J. Glaciol., 3, 1051-1052, 1961.

Martin, S., E. Josberger, and P. Kaufman, Wave induced heat transfer to an iceberg, in Iceberg Utilization, edited by A. Husseiny, pp. 260-264, Pergamon, New York, 1978.

Morgan, V. I., and W. F. Budd, The distribution, movement and melt rate of Antarctic icebergs, in Iceberg Utilization, edited by A. Husseiny, pp. 220-228, Pergamon, New York, 1978.

Neal, V. T., S. Neshyba, and W. Denner, Thermal stratification in the Arctic Ocean, Science, 166, 373-374, 1969.

Neshyba, S., Upwelling by icebergs, Nature, 267, 507-508.

Neshyba, S., and E. G. Josberger, On the estimation of Antarctic iceberg melt rate, J. Phys. Oceanogr., 10, 1681-1685, 1980.

Robin, G. deQ., Formation, flow and disintegration of ice shelves, $J$. Glaciol., 24, 259-271, 1979.
Tressler, W. L., and A. M. Ommundsen, Seasonal oceanographic studies in McMurdo Sound, Antarctica, Rep. TR-125, U.S. Navy Hydrographic Office, Washington, D. C., 1962.

U.S. Hydrographic Office, Sailing directions for Antarctica, Publ. 27, 433 pp., Washington, D. C., 1960.

Weeks, W. F., and W. J. Campbell, Icebergs as a freshwater source: An appraisal, J. Glaciol., 12, 207-233, 1973.

Weertman, J., Deformation of floating ice shelves, J. Glaciol., 3, 3842, 1957.

Weiss, R. F., H. G. Ostlund, and H. Craig, Geochemical studies of the Weddell Sea, Deep Sea Res., 26, 1093-1120, 1979.

Zotikov, I. A., V. S. Zagorodnov, and J. V. Raikovsky, Core drilling through the Ross lce Shelf (Antarctica) confirmed basal freezing Science, 207, 1463-1465, 1980.

(Received October 20, 1980; revised February 23, 1981; accepted April 1, 1981.) 